\begin{tabular}{ccl}
\hline 34 Jurnal Teknologi Kimia Unimal & $\begin{array}{l}\text { Jurnal } \\
\text { Teknologi } \\
\text { Kimia } \\
\text { Unimal }\end{array}$ \\
\hline \hline
\end{tabular}

\title{
PENGARUH WAKTU FERMENTASI DAN BERAT BONGGOL NANAS PADA PEMBUATAN VIRGIN COCONUT OIL (VCO)
}

\author{
Ishak, Amri Aji, Israwati \\ Jurusan Teknik Kimia Fakultas Teknik Universitas Malikussaleh \\ Email: ishgi@yahoo.co.id
}

\begin{abstract}
Abstrak
Kelapa adalah tanaman tropis dan dapat diolah menjadi berbagai macam produk makanan dan minyak kelapa salah satunya adalah Virgin Coconut Oil (VCO). Kelapa dapat diolah menjadi VCO dengan cara fermentasi dengan menggunakan bonggol nanas dan tanpa menggunakan bonggol nanas. Bonggol nanas dapat mempercepat proses terbentuknya minyak dari santan kelapa karena menjadi nutrient bagi mikroba bromilin untuk memperbanyak diri sehingga santan kelapa sebagai substrat berubah menjadi produk minyak. Waktu fermentasi dan berat bonggol nanas menjadi variabel pengujian terhadap banyaknya santan kelapa yang digunakan sangat mempengaruhi rendemen minyak dan kualitas VCO yang di hasilkan. Vaiabel waktu yang diuji selama 24, 30, 36, 42, 48, dan 54 jam. Untuk perlakuan penelitian ini juga divariasikan berat bonggol nanas 30, 35, 40, dan 45 gram. Rendeman VCO terbanyak didapat pada 40 gram bonggol nanas dan waktu fermentasi 36 jam yaitu, 28,8\% dengan kandungan asam lemak bebas (ALB) terbaik dihasikan pada proses pembuatan VCO tanpa bonggol nanas yaitu 0,04\% dengan waktu fermentasi 24 jam. Kadar air terbaik dihasilkan pada proses pembuatan VCO tanpa bonggol nanas yaitu 0,01\% dengan waktu fermentasi 24 jam. Densitas terbaik dihasilkan pada proses pembuatan VCO tanpa menggunakan bonggol nanas yaitu $0,915 \mathrm{gr} / \mathrm{ml}$ dengan waktu fermentasi 48 dan 54 jam. Rendemen VCO terbaik dihasilkan pada proses pembuatan VCO menggunakan 40 gram bonggol nanas yaitu dengan waktu 36 jam.
\end{abstract}

Kata kunci: Virgin Coconut Oil, fermentasi, bonggol nanas, asam lemak bebas, kadar air, densitas

\section{Pendahuluan}

Minyak kelapa diperoleh dari kopra (meat cocanut) atau daging buah kelapa yang difermentasi secara alamiah, digiling atau dikukur kemudian daging buahnya dijemur dengan sinar matahari dan setelah itu dipress dengan mesin press atau alat press (peuneurah) dengan kadar air dalam minyak kelapa $<3 \%$ ). Pada pengolahan minyak kelapa dengan metode fermentasi alamiah minyaknya harus 
diolah kembali untuk meningkatkan kualitasnya, di samping itu rendemen minyaknyahanya $40 \%$. Hal ini disebabkan tumbuhnya jamur seperti Rhizopus sp., Aspergillus flavus, Aspergillus niger, Penicillium glaucum dan Aspergillus famarii pada kopra selama fermentasi berjalan. Berdasarkan alasan ini maka pengolahan minyak kelapa dari bahan segar atau santan kelapa merupakan salah satu alternatif agar dapat diperoleh produksi minyak kelapa dengan rendemen dan kualitas yang tinggi. Minyak kelapa dengan fermentasi santan kelapa atau VCO banyak digunakan sebagai bahan obat-obatan karena dapat menyembuhkan berbagai penyakit kulit, mata, dan penyakit rontok rambut.(Setiaji dan Prayugo, 2006).

Santan adalah cairan yang diperoleh dengan melakukan pemerasan terhadap daging buah kelapa parutan. Pengolahan santan menjadi minyak kelapa murni (VCO) dapat dilakukan dengan tanpa proses pemanasan merupakan proses pengolahan menggunakan enzim atau mikroba penghasil enzim-enzim yang berperan pada pemisahan ikatan lemak dengan protein dan karbohidrat. Dengan cara itu minyak akan langsung terpisah pada lapisan atas.

\subsection{Nanas (Ananas comosus)}

Nanas atau (Ananas comosus) adalah sejenis tumbuhan tropis yang berasal dari Brasil, Bolivia, dan Paraguay. Tumbuhan ini termasuk dalam familia nanasnanasan (Famili Bromeliaceae). Nanas mengandung air 90\% dan kaya akan kalium, kalsium, iodium, sulfur, khlor, dan enzim bromelin. Enzim adalah protein yang mengkatalisis reaksi kimia dan mempengaruhi kecepatan reaksi tetapi tidak ikut dalam reaksi. Enzim berperan sebagai biokatalisator. Komponen utama enzim adalah molekul protein (polipeptida). Enzim bersifat spesifik artinya hanya mengkatalisis suatu reaksi yang dirancang khusus untuk enzim tertentu, misalnya enzim protease penggunaannya dalam pengempukan daging, dan mengekstrak minyak dari daging buah kelapa (Mona, 2009). 


\subsection{Fermentasi}

Fermentasi adalah suatu reaksi oksidasi dan reduksi dalam sistem biologi yang menghasilkan energi dimana donor aseptor adalah senyawa organik. Senyawa organik yang biasa digunakan adalah gula, senyawa ini akan diubah oleh reaksi reduksi dengan katalis enzim menjadi senyawa lain. Enzim ini dihasilkan dari aktifitas mikroba dalam bonggol nanas adalah enzim bromolin. Penambahan enzim bromelin dapat mempercepat proses perusakan sistem emulsi santan yang akan dihidrolisis menjadi asam-asam amino melalui ikatan peptida. Aktifitas enzim bromelin dipengaruhi oleh kematangan buah nanas dan konsentrasi pemakaian. Semakin banyak nanas yang digunakan, semakin cepat proses pemecahan lipoprotein dalam emulsi lemak. Di dalam enzim bromelin terdapat senyawa antioksidan yang berasal dari batang buah nanas khususnya senyawa zat warna alamiah (karoten) yang ikut larut ke dalam minyak.

\subsection{Minyak Kelapa}

Pembuatan VCO dengan cara enzimatis merupakan proses pemutusan ikatan protein santan kelapa dengan yaitu enzim bromelin. Enzim bromilin terdapat pada buah nanas, dan daging ketam. VCO yang ingin dihasilkan menggunakan bonggol nanas sebagai penghasil enzim bromilin untuk menguraikan protein yang terdapat di dalam air santan kelapa. Penggunaan bongggol nanas sebagai bahan pengurai protein santai air kelapa diharapkan dapat memberikan perbedaan volume minyak kelapa yang lebih banyak dan dapat menghasilkan minyak kelapa dengan mutu yang lebih baik dengan cara memvariasikan berat bonggol nanas dengan air santam kelapa.

\section{Baham dan Metode}

Bahan dan peraltan yang digunakan dalam penelitian ini untuk kelangsungan kegiatan perlakuan dan uji dan analisa hasil. Bahan utama yang dibutuhkan adalaha kelapa, bonggol nanas dan aquades. Bahan lain yang mendukungnya yaitu etanol 96\%, indikator PP 1\%, dan $\mathrm{NaOH} \mathrm{0,1} \mathrm{N.} \mathrm{Peralatan}$ 
yang akan digunakan untuk mendukung keberhasilan penelitian dirankai dalam suatu wadah fermentasi dan tambah peralatan lain diantaranya pemarut kelapa, timbangan, mesin pengepres, serta alat analisa lainnya.

Proses pembuatan Virgin Coconut Oil (VCO) atau minyak kelapa murni menggunakan bonggol nanas dilaksanakan melalui tahapan persiapan bahan dan peralatan, tahapan persiapan bahan untuk fermentasi, tahapan fermentasi, dan tahapan analisa. Proses fermentasi berlangsung dalam kondisi tertutup bebas udara, dan beroperasi pada temperatur ruangan dengan voume santan $250 \mathrm{ml}$, Perlakuan penelitian dilaksanakan pada waktu yang divariasikan bersama varasi berat bonggol nanas untuk masing-masing pengujian. Variasi waktu fermentasi yang digunakan selama 24, 30, 36, 42, 48, dan 54 jam. Untuk perlakuan penelitian ini juga divariasikan berat bonggol nanas 30, 35, 40, dan 45 gram. Minyak yang dihasilkan dilakukan pemisahan dari protein dengan proses ekstraksi selama 2 jam. Produk hasil fermentasi berupa minyak kelapa murni (Virgin Coconut Oil) yang sudah dipisahkan dari kotoran-kotoran nya dilakukan pengujian dan analisa terhadap rendemen minyak, asam lemak bebas (ALB), densitas ( $\mathrm{gr} / \mathrm{ml})$, dan kadar air. Analisa dilakukan untuk dapat mengetahui kualitas dari VCO yang dihasilkan.

\section{Hasil dan Diskusi}

Berdasarkan data yang diperoleh setelah dilakukan penelitian maka dapat diketahui asam lemak bebas, kadar air, densitas dan rendemen minyak, dengan variasi berat bonggol nanas dan waktu fermentasi. Penelitian yang dilakukan menunjukkan bahwa setiap perlakuan dari masing-masing variabel memberikan pengaruh terhadap produk yang dihasilkan. Untuk lebih jelasnya bagaimana pengaruh dari parameter yang diamati terhadap pengolahan jumlah produk yang dihasilkan dapat didiskusikan.

\subsection{Pengaruh Waktu Fermentasi dan Berat Bonggol Nanas terhadap Asam Lemak Bebas pada Pembuatan VCO}

Gambar 1 menunjukkan bahwa, pengaruh waktu fermentasi dan berat bonggol nanas terhadap asam lemak bebas pada proses pembuatan VCO. 
Kandungan asam lemak bebas dipengaruhi oleh waktu fermentasi dan berat bonggol nanas. Semakin lama waktu fermentasi dan semakin banyak bonggol nanas yang ditambahkan, kandungan asam lemak bebas semakin meningkat. Pada waktu fermentasi 54 jam, kandungan asam lemak bebas tertinggi terdapat pada berat bonggol nanas 45 gram sebesar 0,42\% dan asam lemak bebas terendah terdapat pada berat bonggol nanas 30 gram sebesar $0,11 \%$. Kandungan asam lemak bebas (ALB) yang tinggi pada minyak disebabkan karena adanya kandungan air di dalam bonggol nanas. Kandungan air dalam minyak dapat mempercepat terjadinya proses hidrolisis minyak kelapa. Minyak yang mengandung asam lemak jenuh dapat terhidrolisis menjadi asam lemak bebas dan gliserol dengan adanya air. VCO mengandung asam lemak jenuh sekitar 90\% sehingga kemungkinan terjadi proses hidrolisis sangat besar.

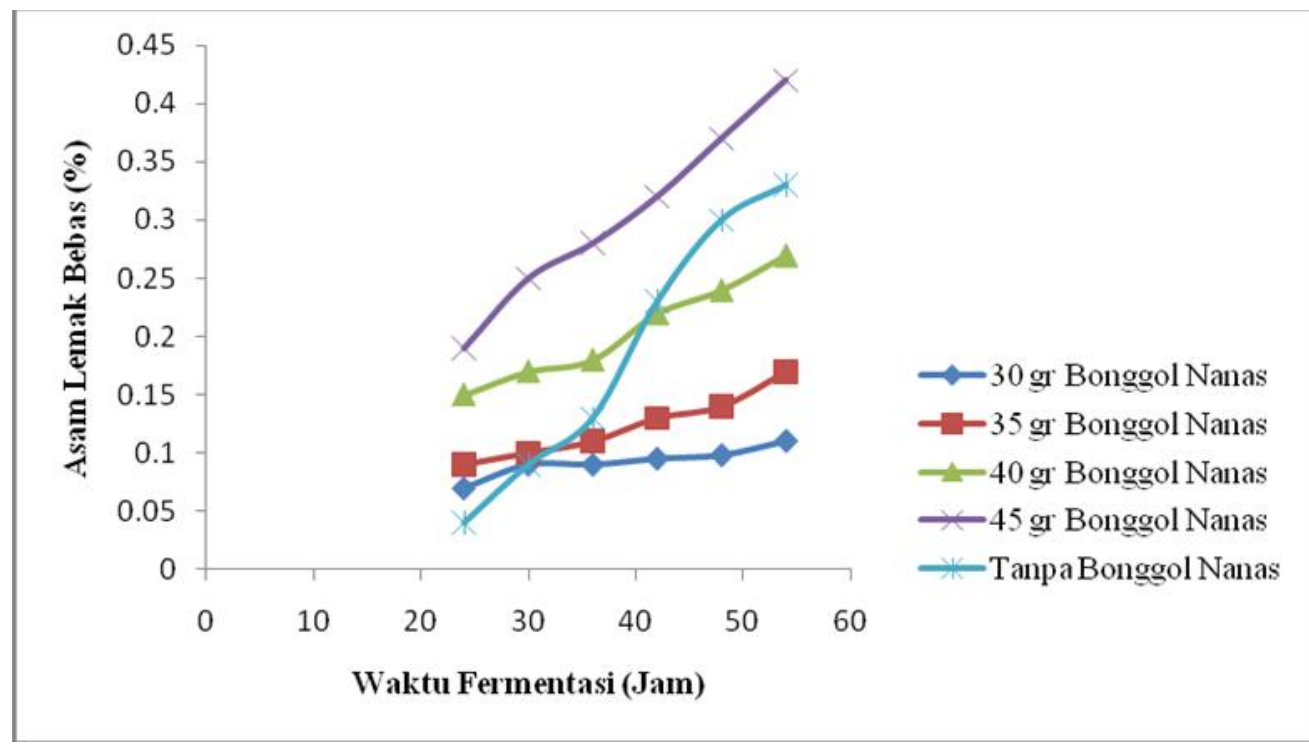

Gambar 1 Grafik Hubungan Asam Lemak Bebas terhadap Waktu Fermentasi dan Berat Bongggol Nanas pada Pembuatan VCO

Menurut Standar Nasional Indonesia (2008), kandungan asam lemak bebas maksimum yang diperbolehkan dalam VCO adalah 0,2\%. Berdasarkan gambar 1 tersebut, sebagian VCO yang didapat telah memenuhi standar yang telah ditetapkan. Kandungan asam lemak bebas yang diatas standar terdapat pada VCO 
waktu fermentasi 30 jam dengan berat bonggol nanas $45 \mathrm{gr}$, VCO waktu fermentasi 36 jam dengan berat bonggol nanas 45 gr, VCO waktu fermentasi 42 jam dengan berat bonggol nanas 40 dan 45 gr, VCO waktu fermentasi 48 jam dengan berat bonggol nanas 40 dan 45 gr, VCO waktu fermentasi 54 jam dengan berat bonggol nanas 40 dan 45 gr, VCO tanpa bonggol nanas dengan waktu fermentasi 42, 48 dan 54 jam.

\subsection{Pengaruh Waktu Fermentasi dan Berat Bonggol Nanas terhadap Kadar Air pada Proses Pembuatan VCO}

Berdasarkan Gambar 2 dapat dilihat bahwa pada waktu fermentasi 24 jam, kadar air tertinggi terdapat pada berat bonggol nanas 45 gram sebesar $0,06 \%$ dan kadar air terendah terdapat pada berat bonggol nanas 30 gram sebesar 0,02\%. Pada waktu fermentasi 54 jam, kadar air tertinggi terdapat pada berat bonggol nanas 45 gram sebesar $0,13 \%$ dan kadar air terendah terdapat pada berat bonggol nanas 30 gram sebesar 0,09\%. Untuk penggunaan bonggol nanas yang semakin meningkat kadar air yang terbentuk juga semakin meningkat.

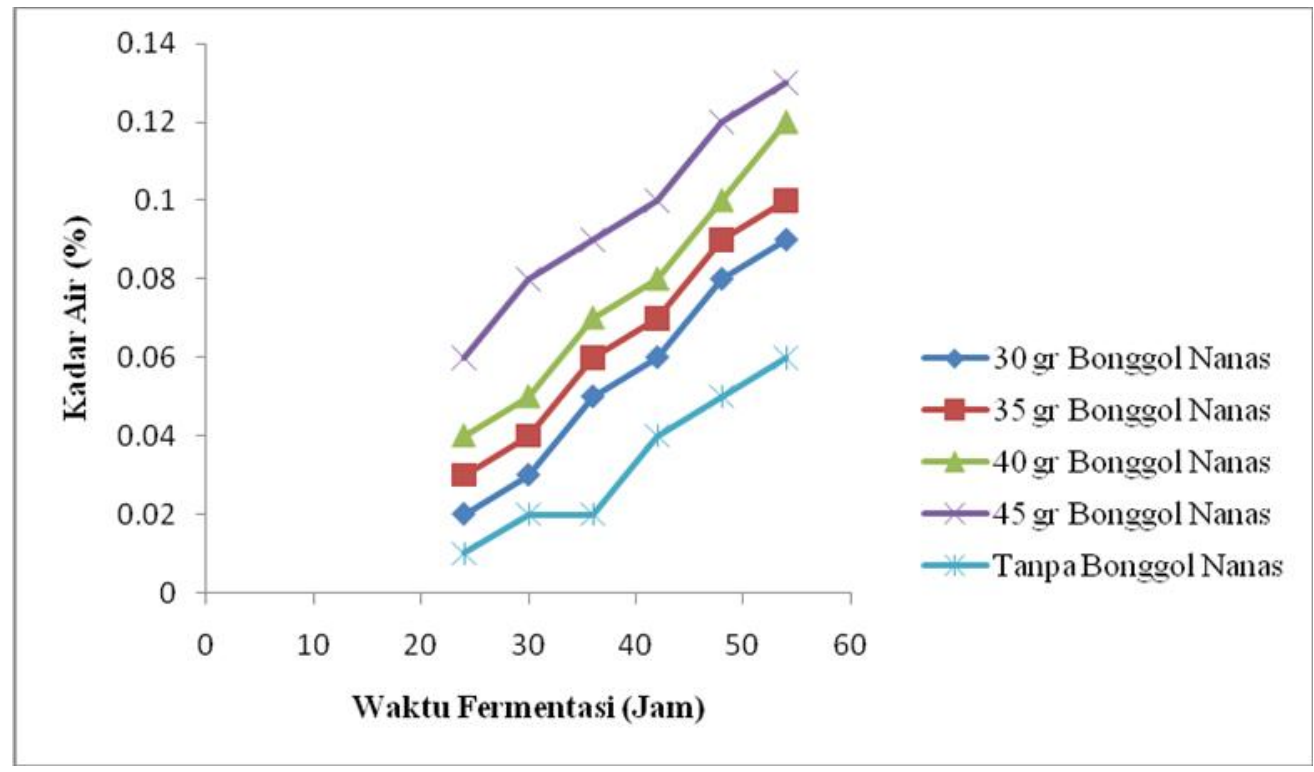

Gambar 2 Grafik Hubungan Kadar Air terhadap Waktu Fermentasi dan Berat Bongggol Nanas pada Proses Pembuatan VCO 
Waktu fermentasi dan berat bonggol nanas yang ditambahkan dapat mempengaruhi kadar air yang dihasilkan. Semakin lama waktu fermentasi dan semakin banyak bonggol nanas yang ditambahkan maka kadar air yang diperoleh semakin tinggi. Hal ini disebabkan karena nanas adalah buah tropis yang mempunyai kandungan air yang tinggi yaitu 90\% sehingga besarnya penambahan jumlah bonggol nanas akan mempengaruhi kandungan air dalam minyak juga besar. Kadar air secara umum meningkat dengan bertambahnya waktu fermentasi, hal ini dapat dilihat dari kenaikkan yang ditunjukkan oleh waktu fermentasi 54 jam dibandingkan dengan 48 jam.

Kadar air sangat menentukan kualitas dari minyak VCO. Kadar air berperan dalam proses oksidasi maupun hidrolisis minyak yang akhirnya dapat menyebabkan ketengikan. Semakin tinggi kadar air, maka ketengikan minyak semakin cepat. Minyak VCO yang berkadar air tinggi akan cenderung memiliki masa simpan pendek. Kerusakan minyak dapat dipercepat oleh adanya air, protein, karbohidrat dan bahan lain. Tingginya kadar air tersebut dapat mempercepat proses hidrolisis. Hidrolisis minyak ini menghasilkan asam-asam lemak bebas yang mempengaruhi cita rasa dan bau. Menurut Standar Nasional Indonesia (2008), kadar air yang diperbolehkan dalam minyak adalah maksimum $0,2 \%$. Dengan demikian, kandungan air yang terkandung dalam minyak VCO telah sesuai dengan SNI.

\subsection{Pengaruh Waktu Fermentasi dan Berat Bonggol Nanas terhadap Densitas pada Proses Pembuatan VCO}

Gambar 3 menunjukkan bahwa pengaruh waktu fermentasi terhadap kenaikan densitas tidak begitu signifikan. Sedangkan pengaruh berat bongkol nanas terlihat cukup signifikan. Dengan demikian, dari waktu fermentasi 24-36 jam densitas VCO mengalami peningkatan sedangkan pada waktu fermentasi 42 jam terjadi penurunan dan peningkatan. Waktu fermentasi tidak berpengaruh terhadap densitas minyak VCO yang terbentuk. Hal ini karena densitas VCO dipengaruhi oleh berat molekul dan komponen-komponen dalam minyak, serta ketidak jenuhan komponen asam lemak minyak. 
Densitas VCO dari masing-masing perlakuan berbeda tidak jauh. Hal ini dikarenakan dalam pemisahan minyak menggunakan metode ekstraksi cair-cair, sehingga memungkinkan adanya zat-zat yang lolos pada saat pemisahan seperti kotoran, protein, dan zat-zat lain yang dapat mempengaruhi besarnya berat jenis minyak. Berat bonggol nanas dapat mempengaruhi densitas VCO, semakin banyak bonggol nanas yang ditambahkan semakin besar densitas yang terbentuk. Hal ini disebabkan oleh aktifitas enzim dalam memecah ikatan protein yang mengikat minyak kelapa tersebut. Kadar air minyak serta zat- zat yang lolos pada saat penyaringan minyak seperti kotoran, protein, garam mineral, dapat mempengaruhi besarnya densitas minyak.

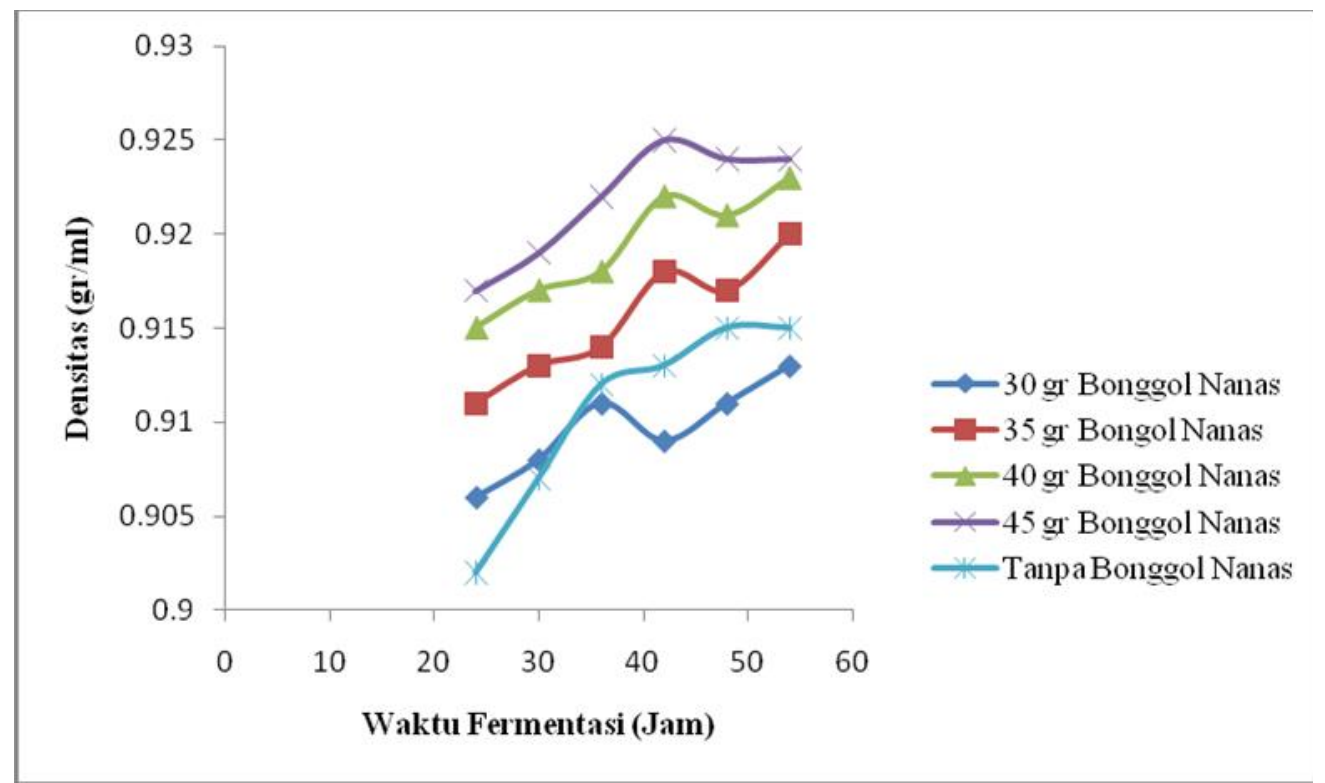

Gambar 3 Grafik Hubungan Densitas terhadap Waktu Fermentasi dan Berat Bongggol Nanas pada Proses Pembuatan VCO

Berdasarkan gambar 3 tersebut, naik turunnya densitas juga dipengaruhi karena proses penyaringan minyak menggunakan kertas saring biasa, sehingga memungkinkan adanya zat-zat yang lolos pada saat penyaringan. Menurut Asian and Pasific Coconut Community (AFCC), standar mutu densitas VCO adalah berkisar antara 0.915-0.920 gr/ml. Dengan demikian, densitas VCO dari semua 
variabel didapatkan beberapa yang sesuai dengan standar mutu, tetapi ada juga beberapa yang berada di bawah standar mutu tersebut.

\subsection{Pengaruh Waktu Fermentasi dan Berat Bonggol Nanas terhadap Rendemen Minyak pada Proses Pembuatan VCO}

Rendemen minyak kelapa ini bertujuan untuk melihat persentase kandungan minyak yang dihasilkan. Berdasarkan Gambar 4, pada proses pembuatan VCO menggunakan bonggol nanas rendemen minyak tertinggi terdapat pada waktu fermentasi 42 jam sebesar $35.2 \%$ dan rendemen minyak terendah terdapat pada waktu fermentasi 24 jam sebesar 16\%. Pada proses pembuatan VCO tanpa menggunakan bonggol nanas rendemen minyak tertinggi terdapat pada waktu fermentasi 48 jam yaitu sebesar 13,2\% dan rendemen minyak terendah terdapat pada waktu fermentasi 24 jam sebesar 5,52\%.

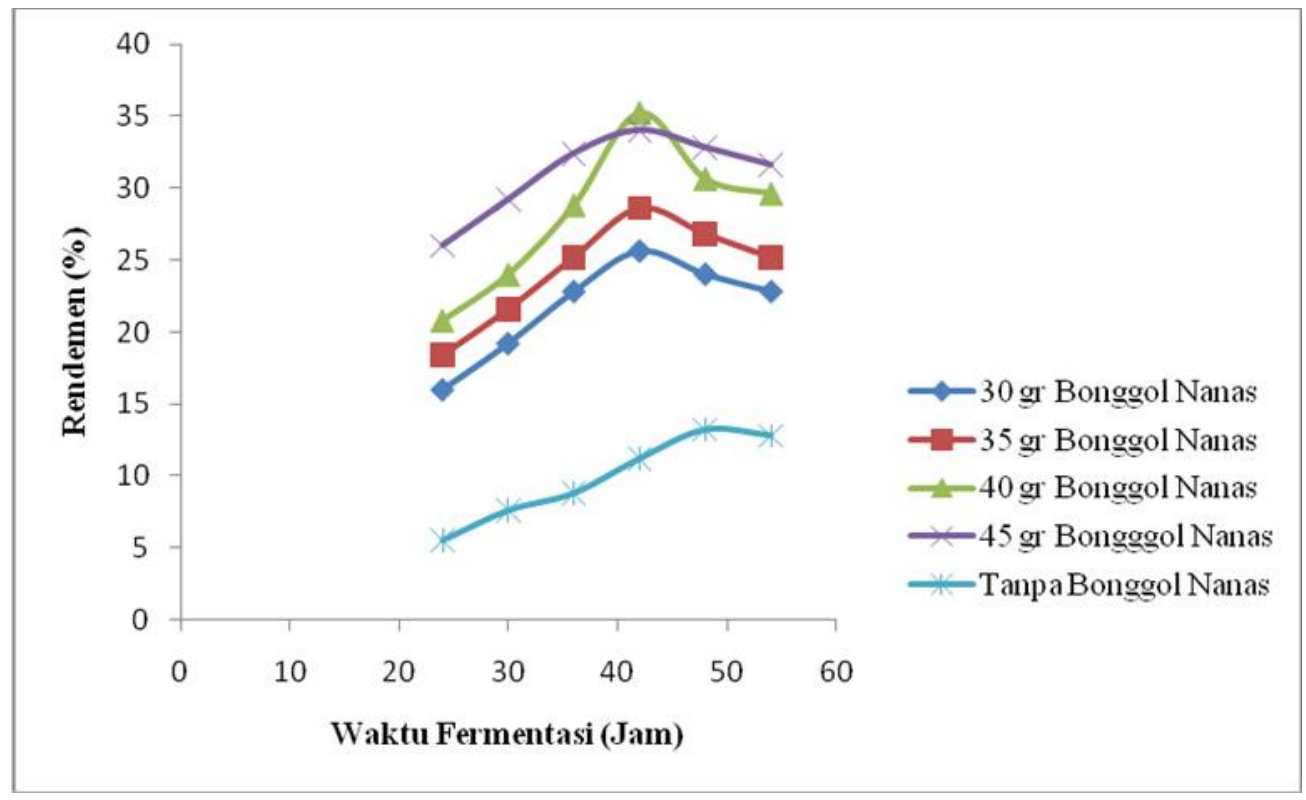

Gambar 4 Grafik Hubungan Rendemen terhadap Waktu Fermentasi dan Berat Bonggol Nanas pada Proses Pembuatan VCO

Semakin lama waktu fermentasi dan semakin banyak bonggol nanas yang ditambahkan, maka rendemen minyak yang dihasilkan semakin tinggi hingga waktu 42 jam. Hal ini terjadi disebabkan karena pemecahan emulsi santan 
berjalan dengan sempurna. Tetapi rendemen pada waktu fermentasi 48 jam mulai menurun karena disebabkan fermentasi oleh unsur-unsur penyusun minyak sebagai sumber dan pertumbuhan sel enzim bromelin sudah habis atau enzim sudah mati. Rendahnya rendemen yang diperoleh juga dipengaruhi oleh kandungan minyak yang terdapat dalam kelapa dan enzim bromelin yang terkandung dalam bonggol nanas.

Waktu fermentasi yang semakin lama proses pemecahan emulsi santan terus berlangsung, kecepatan reaksi hidrolisis protein semakin meningkat sehingga minyak yang dapat dibebaskan dari selubung protein juga semakin banyak sehingga rendemen semakin tinggi. Peningkatan rendemen minyak yang terjadi juga disebabkan karena pada awal fermentasi sel-sel enzim bromelin berada dalam keadaan pertumbuhan sehingga mencapai jumlah yang maksimum. Dengan demikian enzim pemecah protein berada dalam keadaan maksimum. Bila kita lihat dari hasil penelitian ini menunjukkan pengaruh yang signifikan pada waktu fermentasi dalam waktu yang terbatas, dan juga pengaruh berat dari bonggol nanas.

\section{Simpulan}

Dari hasil penelitian dan pembahasan dapat diambil beberapa kesimpulan sebagai berikut:

1. Berat bonggol nanas yang digunakan dalam proses pembuatan VCO dapat mempengaruhi kandungan Asam Lemak Bebas, kandungan air, densitas dan rendemen minyak. Semakin banyak bonggol nanas maka Asam Lemak Bebas, kadar air, densitas dan rendemen minyak yang dihasilkan semakin tinggi.

2. Kondisi terbaik batas penelitian ini untuk menghasilkan minyak VCO dengan rendemen tertinggi serta kualitas yang sesuai dengan SNI adalah pada proses pembuatan VCO menggunakan 40 gr bonggol nanas pada waktu fermentasi 36 jam, dengan hasil rendemen 28,8\%, Asam lemak bebas 0,18\%, kadar air $0,07 \%$ dan densitas $0,19 \%$. 


\section{Saran}

Penelitian selanjutnya sebaiknya menggunakan sebagai bonggol buah namas yang belum masak, karena dapat menghasilkan enzim lebih banyak sehingga proses pemecahan emulsi santan lebih cepat.

\section{Daftar Pustaka}

1. Amin, S., 2009. "Cocopreneurship”. Yogyakarta : Lily Publisher.

2. Badan Standarisasi Nasional, 2008. "Minyak Kelapa Virgin Coconut Oil (VCO)" SNI 7381:2008.

3. Cahyono, L. U., 2012. Proses Pembuatan VCO (Virgin Coconut oil) dengan Fermentasi menggunakan Starter Tempe. Jurnal Teknik Kimia, Universitas Diponegoro.

4. Diyah, N. W., 2010. Pembuatan Minyak Kelapa Secara Enzimatis dengan Memanfaatkan Kulit Buah dan Biji Pepaya Serta Analisis Sifat Fisikokimianya. Departement Kimia, Universitas Airlangga.

5. Effendi, AM., 2012. Optimalisasi Penggunaan Enzim Bromelin dari Sari Bonggol Nanas dalam Pembuatan Minyak Kelapa. Indonesian Journal of Chemical Science. Universitas Negeri Semarang.

6. Fajrin, E., 2012. Application of the Bromelain Enzyme in the Making of Coconut (Cocos nucifera) Oil Enzymatically”. Universitas Hasanuddin. Makassar.

7. Ferdiansyah, V. 2005. Pemanfaatan Kitosan dari Cangkang Udang Sebagai Matriks Penyangga pada Imobilisasi Enzim Protease. Skripsi. Jurusan Teknologi Hasil Pertanian. Fakultas Perikanan dan Ilmu Kelautan. Institut Pertanian Bogor. Bogor.

8. Fesesenden, Ralp J, dan Jan, Fessenden, 1982."Kimia Organik”, Edisi III, Erlangga, Jakarta.

9. Ketaren, S., 1986, Pengantar Teknologi Minyak dan Lemak Pangan, Penerbit Universitas Indonesia (UI-Press), Jakarta.

10. Moeksin, R., 2008. Pengaruh Penambahan Papain Terhadap Kualitas VCO dengan Metode Enzimatis, Sentrifugasi dan Pemanasan.Jurnal Teknik Kimia, No. 1, Vol. 15. Universitas Sriwijaya.

11. Rindengan, B., dan Hengky, N., 2004, Pembuatan \& Pemanfaatan Minyak Kelapa Murni, Penebar Swadaya, Jakarta. 
12. Setiaji, B dan Surip P., 2006, Membuat VCO Berkualitas Tinggi, Penebar Swadana, Jakarta.

13. Widayat, dkk., 2005. Pembuatan Asam Sitrat dari Buangan Padat Buah Nanas dengan Fermentasi Fase Cair dalam Bioreaktor Bergelembung. Fakutas Teknik. Universitas Diponegoro. 